\title{
ANALISIS PERILAKU PATUH PAJAK ORANG PRIBADI BERDASARKAN THEORY OF PLANNED BEHAVIOR DAN KEPERCAYAAN TERHADAP PEMERINTAH
}

\author{
Dessanti Putri Sekti Ari \\ Fakultas Ilmu Administrasi, Universitas Brawijaya \\ Email: dessantiputrisa@gmail.com
}

\begin{abstract}
ABSTRAK
Perilaku patuh pajak merupakan suatu tindakan nyata yang dilakukan oleh wajib pajak untuk menghitung, menyetor, dan melaporkan pajak. Tingkat kepatuhan pajak di Indonesia masih rendah. Hal ini dibuktikan dengan adanya data dari OECD dan laporan kinerja direktorat jenderal pajak. Oleh karena itu, tujuan penelitian ini adalah untuk menganalisis faktor - faktor yang mempengaruhi perilaku patuh pajak orang pribadi dengan menggunakan Theory of Planned Behavior dan kepercayaan terhadap pemerintah. Variabel yang digunakan dalam penelitian ini adalah sikap, norma subjektif, kontrol perilaku persepsian, kepercayaan terhadap pemerintah, minat patuh pajak, dan perilaku patuh pajak. Pengumpulan data dilakukan dengan menggunakan metode survei online. Populasi penelitian ini adalah wajib pajak orang pribadi di pulau jawa. Metode pengambilan sampel dalam penelitian ini adalah judgement sampling. Penelitian ini menggunakan 120 responden. Metode statistik yang digunakan dalam penelitan ini adalah Warp Partial Least Square (WarpPLS). Hasil penelitian ini menunjukkan bahwa sikap dan norma subjektif berpengaruh positif terhadap minat patuh pajak dan minat patuh pajak berpengaruh positif terhadap perilaku patuh pajak. Sedangkan kontrol perilaku persepsian tidak berpengaruh positif terhadap minat patuh pajak, kontrol perilaku persepsian dan kepercayaan terhadap pemerintah tidak berpengaruh terhadap perilaku patuh pajak
\end{abstract}

Kata kunci : Perilaku patuh pajak, wajib pajak orang pribadi, Theory of planned behavior

\begin{abstract}
Tax compliance behavior is a real action taken by taxpayers to calculate, deposit, and report taxes. The level of tax compliance in Indonesia is still low. This is evidenced by the data from the OECD and the directorate general of tax performance reports. Therefore, the purpose of this study is to analyze the factors that influence individual tax compliance behavior by using Theory of Planned Behavior and trust in the government. The variables used in this study are attitudes, subjective norms, control of perceived behavior, trust in the government, tax compliance intention, and tax compliance behavior. Data were collected through online survey methods. The population of this study is individual taxpayers on the Java island. The sampling method in this study is judgment sampling. This study used 120 respondents. The statistical method used in this research is Warp Partial Least Square (WarpPLS). The results of this study indicate that attitudes and subjective norms have a positive effect on the tax compliance intention and the tax compliance intention has a positive effect on tax compliance behavior. While perceived behavioral control does not have a positive effect on tax compliance intention, perceived behavioral control and trust in the government have no effect on tax compliance behavior.
\end{abstract}

Keywords: Tax compliance behavior, individual taxpayers, Theory of planned behavior 


\section{A. PENdahuluan}

Kepatuhan pajak adalah sebuah permasalahan umum yang ada di semua negara (Chuck \& Anthony, 2013). Karena pada dasarnya tidak seorang pun suka untuk membayar pajak (Torgler,2002). Padahal pajak adalah salah satu sumber pendapatan yang sangat besar kontribusinya bagi negara.

Menurut data OECD pada tahun 2016, kepatuhan wajib pajak masyarakat Indonesia masih rendah. Hal ini diperkuat dengan adanya laporan kinerja direktorat jenderal pajak tahun 2017 yang mengungkapkan bahwa kurang lebih sebesar 6,8 juta oang wajib pajak tidak melakukan pembayaran dan melaporkan pajaknya. Dan menurut kusuma (2018) di tahun 2017 penerimaan pajak hanya mencapai $91 \%$. Oleh karena itu, sangat penting dilakukan penelitian untuk menganalisis faktor yang mempengaruhi kepatuhan wajib pajak.

Kepatuhan pajak dapat dilihat dari beberapa sudut pandang. Menurut Devos (2015) kepatuhan pajak dapat dilihat dari dua sudut pandang, yaitu ekonomi dan sosiologi psikologi. Penelitian ini berfokus untuk mengetahui faktor-faktor yang mempengaruhi kepatuhan wajib pajak dari sisi psikologi.

Dilihat dari perspektif psikologi, kepatuhan pajak merupakan sebuah perilaku. Salah satu teori yang paling sering digunakan untuk meneliti perilaku adalah theory of planned behavior (Damayanti, Sutrisno, Subekti, Baridwan, 2015). Namun, Theory of Planned Behavior juga memiliki kelemahan dalam menjelaskan hubungan antara perilaku dan minat berperilaku patuh (Damayanti et al., 2015). Menurut Damayanti dan Supomo (2012) salah satu hal yang mendorong perilaku patuh pajak adalah adanya persepsi dari wajib pajak terhadap pemerintah. Semakin warga negara percaya terhadap pemerintah, maka mereka akan semakin patuh terhadap peraturan (levi dan Stoker, 2000). Menurut Birskyte (2014) wajib pajak akan termotivasi untuk membayar pajak apabila mereka percaya terhadap pemerintah. Birskyte (2014) membuktikan bahwa kepercaayan terhadap pemerintah berpengaruh terhadap perilaku patuh pajak. Oleh karena itu, dalam penelitian ini menambahkan variable kepercaan pemerintah ke dalam model Theory of planned behavior. Pada akhirnya, penelitian ini menggunakan 5 variabel, antara lain sikap, norma subjektif, kontrol perilaku persepsian, minat perilaku, kepercayaan terhadap pemerintah, minat patuh pajak, dan perilaku patuh pajak.

Berdasarkan uraian di atas, maka tujuan dari penelitian ini adalah untuk mengetahui pengaruh sikap terhadap minat patuh pajak, untuk mengetahui pengaruh norma subjektif terhadap minat berperilaku patuh pajak, untuk mengetahui pengaruh kontrol perilaku persepsian terhadap minat berperilaku patuh pajak, untuk mengetahui kontrol perilaku persepsian terhadap perilaku patuh pajak, untuk mengetahui pengaruh kepercayaan terhadap pemerintah terhadap perilaku patuh pajak, untuk mengetahui pengaruh minat patuh pajak terhadap perilaku patuh pajak.

\section{B. KAJIAN PUSTAKA}

\section{Perilaku Patuh Pajak}

Menurut Hartono (2007: 11) perilaku adalah

'tindakan-tindakan atau reaksi-reaksi dari suatu objek atau organisma. Perilaku dapat berupa sadar atau tidak sadar, terus terang atau diam-diam, sukarela, atau tidak sukarela".

Perilaku manusia dapat berupa perilaku yang umum, tidak umum, dapat diterima atau tidak dapat diterima. Manusia mengevaluasi penerimaan dari perilaku dengan menggunakan suatu standar pembandingan yang disebut norma-norma sosial dan meregulasi perilaku dengan menggunakan kontrol sosial.

Menurut Gunadi (2005:14) kepatuhan perpajakan adalah

' kesediaan dari wajib pajak untuk memenuhi kewajiban pajaknya sesuai dengan aturan yang berlaku tanpa perlu diadakannya pemeriksaan, investigasi sesakma, peringatan dan ancaman dan penerapan sanksi baik hukum maupun administrasi'".

Menurut Macfud (Rahayu, 2010:137-138) kepatuhan perpajakan berarti

"setiap secara sukarela melakukan self assessment system, dimana Wajib Pajak bertanggung jawab menetapkan sendiri kewajiban perpajakannya secara akurat, membayar, dan dan melaporkan pajaknya tersebut'.

Berdasarkan definisi diatas dapat disimpulkan perilaku patuh pajak adalah tindakan sukarela wajib pajak dalam memenuhi kewajiban perpajakannya berdasarkan peraturan yang berlaku, yang meliputi menghitung, membayar dan melaporkan jumlah pajaknya sendiri. 


\section{Wajib Pajak Orang Pribadi}

Berdasarkan UU No 16 tahun 2009 tentang perubahan keempat atas UU No 6 tahun 1983 pengertian Wajib Pajak adalah

'orang pribadi atau badan meliputi pembayar pajak, pemotong pajak, dan pemungut pajak yang mempunyai hak dan kewajiban perpajakan sesuai dengan ketentuan peraturan perundang-undangan perpajakan'”

Sedangkan yang dimaksud dengan wajib pajak orang pribadi adalah subjek pajak pribadi yang sudah memiliki pengkasilan di atas pendapatan tidak kena pajak.

\section{Theory Of Planned Behavior}

Theory of planned behavior merupakan salah satu teori yang mempelajari perilaku manusia. Teori ini dikembangkan oleh Ajzen (1998). Seseorang akan melakukan perilaku apabila berminat untuk melakukannya. Ada dua penentu dasar yang dapat mempengaruhi minat perilaku seseorang, yaitu sikap dan norma subjektif (Hartono, 2007:31). Sikap adalah perasaan positif dan negatif dari individu jika harus melakukan suatu. Sedangkan norma subjektif adalah persepsi seseorang terhadap tekanan sosial. Ajzen (1988) menambahkan variabel kontrol perilaku persepsian ke dalam model Theory of reasoned Action. Sehingga tercipta sebuah model baru yang dikenal sebagai Theory of planned behavior. Menurut Hartono (2007:62) :

"variable kontrol perilaku persepsian mempunyai implikasi motivasional terhadap minat".

Variabel-variabel yang terdapat pada theory of planned behavior antara lain adalah sikap perilaku,norma subjektif,control perilaku persepsian, minat perilaku, dan perilaku.

\section{Definisi Dan Pengukuran Variabel}

Penelitian ini menggunakan variabel sikap, norma subjektif, kontrol perilaku persepsian, kepercayaan terhadap pemerintah, minat berperilaku patuh, dan perilaku patuh pajak. Berikut ini adalah definisi dan pengukuran dari masing-masing variabel:

Sikap. Menurut Fishbein dan Ajzen (1975) sikap merupakan

"perasaaan seseorang untuk menerima atau menolak perilaku'.

Sikap dalam penelitian ini diukur dengan menggunakan indikator Saad (2009).

Norma Subjektif. Menurut Jogiyanto (2007: 42) norma subjektif adalah 'persepsi seseorang terhadap kepercyaan orang lain yang bisa mempengaruhi minat untuk melakukan atau tidak melakukan perilaku". Norma subjektif dalam penelitian ini diukur dengan menggunakan indikator yang digunakan oleh Taylor and todd (1995).

Kontrol perilaku persepsian. Kontrol perilaku persepsian menurut Hartono (2007:64) adalah

"persepsi kemudahan atau kesulitan untuk melakukan sesuatu'.

Kontrol perilaku persepsian dalam penelitian ini diukur dengan menggunakan indikator yang digunakan oleh Rosid (2017).

Kepercayaan terhadap Pemerintah. Menurut Jimenez dan Iyer (2016) kepercayaan pada pemerintah adalah

"kesediaan warga negara untuk rentan terhadap tindakan pemerintah meskipun ketidakmampuannya untuk secara aktif mengendalikan tindakan pemerintah".

Kepercayaan terhadap pemerintah diukur dengan menggunakan indikator yang digunakan oleh Miller (1974).

Minat Patuh Pajak. Menurut Hartono (2007:29) minat adalah

"'keinginan seseorang untuk melakukan suatu perilaku yang tertentu'.

Minat berperilaku patuh dalam penelitian ini diukur dengan indikator yang digunakan oleh Saad (2009).

Perilaku Patuh Pajak. Menurut Hartono (2007:26) perilaku adalah 'tindakan atau kegiatan nyata yang dilakukan'.

Perilaku dalam penelitian ini diukur dengan menggunakan indikator yang digunakan oleh Rosid (2017).

\section{Model Penelitian}

Penelitian ini mengembangkan Theory of Planned Behavior dengan menambahkan variabel kepercayaan terhadap pemerintah. Berikut ini adalah model penelitiannya:

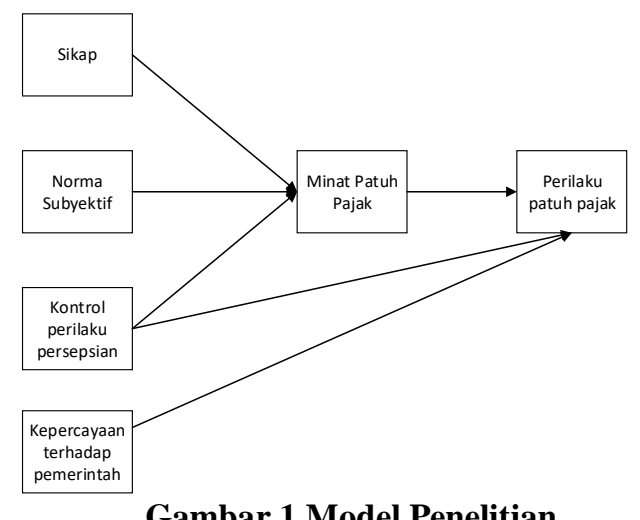

Gambar 1 Model Penelitian 
Berdasarkan model penelitian di atas, ,maka hipotesis dalam penelitian ini adalah :

H1 : Sikap berpengaruh positif terhadap minat patuh pajak

H2 : Norma subyektif berpengaruh positif terhadap minat patuh pajak.

H3 :Kontrol perilaku berpengaruh positif terhadap minat patuh pajak.

H4 : Kontrol perilaku berpengaruh positif terhadap perilaku patuh pajak

H5 : Kepercayaan terhadap pemerintah berpengaruh positif terhadap perilaku patuh pajak.

H6 : Minat patuh pajak berpengaruh positif terhadap perilaku patuh Pajak

\section{METODE PENELITIAN}

Populasi penelitian ini adalah wajib pajak orang pribadi yang ada di Pulau Jawa. Metode pengambilan sampel dalam penelitian ini adalah judgment sampling. Adapun kriteria dalam penelitian ini adalah wajib pajak orang pribadi dan memiliki NPWP. Alasan peneliti memilih wajib pajak orang pribadi dan memiliki NPWP adalah karena seseorang yang sudah dewasa dan bekerja bisa menjadi subjek pajak, tetapi dia belum tentu adalah wajib pajak. Karena untuk menjadi wajib pajak dan berNPWP maka orang tersebut harus memenuhi syarat subjektif dan objektif. Dan ketika sudah memiliki NPWP, maka wajib pajak tersebut memiliki kewajiban untuk menyampaikan SPT.

Pengumpulan data dalam penelitian ini menggunakan survey online. Kuesioner mulai disebarkan mulai tanggal 4 November 2018 hingga 30 November 2018. Sebanyak 120 kuesiner telah disebarkan. Dari 120 kuesioner yang telah disebarkan, hanya ada 85 kuesioner yang dapat digunakan. Kuesioner yang lain tidak dapat digunakan karena wajib pajak tersebut tidak sesuai dengan kriteria peneliti. Beberapa di antaranya yang mengisi adalah wajib pajak badan, atau beberapa diantaranya belum memiliki NPWP.

Software statistik yang digunakan dalam penelitian ini adalah Warp Partial Least Square (WarpPLS). Evaluasi model dilakukan dengan melakukan evaluasi outer model dan inner model. Outer model adalah pengukuran untuk menilai validitas dan reliabilitas model. Inner model adalah model struktural untuk memprediksi hubungan kausalitas antar variabel laten. Persamaan inner model dalam penelitian ini adalah:

$$
\begin{aligned}
& \mathrm{M}=\alpha_{1} \mathrm{~S}+\alpha_{2} \mathrm{NS}+\alpha_{3} \mathrm{KPP}+\mathrm{e} \\
& \mathrm{P}=\alpha_{4} \mathrm{M}+\alpha_{5} \mathrm{KPP}+\alpha_{6} \mathrm{KP}+\mathrm{e}
\end{aligned}
$$

Keterangan: $\mathrm{M}$ : Minat berperilaku patuh; S: Sikap; NS: Norma Subjektif; KPP: Kontrol perilaku persepsian;P: Perilaku;KP: Kepercayaan terhadap pemerintah; e : Tingkat kesalahan pengukuran; $\alpha$ n: koefisien variabel

\section{HASIL DAN PEMBAHASAN \\ HASIL}

Hasil evaluasi outer model dan inner model menunjukkan bahwa model penelitian sudah valid dan reliabel. Setelah melakukan evaluasi outer model, maka perlu dilakukan evaluasi inner model. Evaluasi Inner model dilakukan dengan cara melihat hasil estimasi koefisien determinasi, path coefficient, dan $\mathrm{p}$ value.

Tabel 1. Hasil R-square

\begin{tabular}{|l|c|}
\hline Variabel & $\begin{array}{c}\boldsymbol{R}- \\
\text { square }\end{array}$ \\
\hline S, NS, KPP -> Y1 & 0.662 \\
\hline KPP,X4,Y1 -> Y2 & 0.321 \\
\hline
\end{tabular}

Berdasarkan tabel 1 di atas, didapatkan bahwa koefisien determinasi ( $R$-square) variable minat patuh pajak adalah 0,662 $(66,2 \%)$. Hal ini dapat diartikan bahwa variable minat patuh pajak $66,2 \%$ dipengaruhi oleh variabel sikap (S), norma subjektif (NS), kontrol perilaku persepsian (KPP) dan kepercayaan terhadap pemerintah (KP). Sedangkan koefisien determinasi ( $R$-square) variable perilaku patuh pajak adalah 0,321 $(32,1 \%)$, artinya variable perilaku patuh pajak $32,1 \%$ dipengaruhi oleh variabel kontrol perilaku persepsian (KPP), kepercayaan terhadap pemerintah (KP) dan minat patuh pajak (M).

Hasil model path yang terbentuk adalah sebagai berikut:

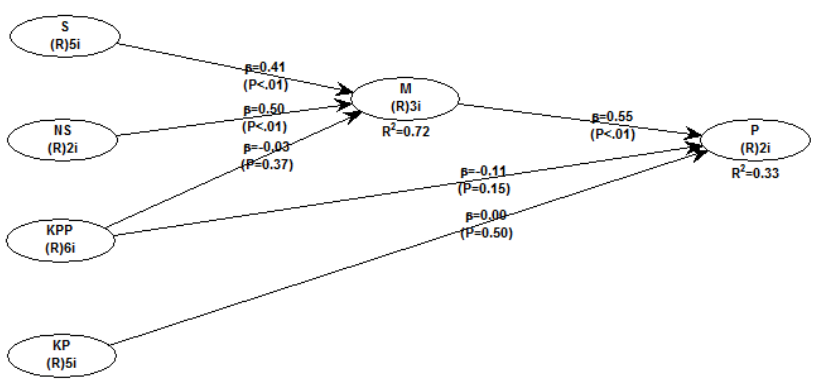

Gambar 2. Model Path 
Tabel 2 Pegujian Hipotesis

\begin{tabular}{|c|c|c|c|c|c|c|}
\hline \multirow{2}{*}{$\begin{array}{l}\text { Hipotesis } \\
\\
\text { H1 }\end{array}$} & \multicolumn{3}{|c|}{ Pengaruh antar variabel Latent } & \multirow{2}{*}{$\begin{array}{c}\begin{array}{c}\text { Koefisien } \\
\text { Jalur }\end{array} \\
0.414 \\
\end{array}$} & \multirow{2}{*}{$\begin{array}{c}\begin{array}{c}\mathrm{p}- \\
\text { value }\end{array} \\
<0.001 \\
\end{array}$} & \multirow{2}{*}{$\begin{array}{l}\text { Kesimpulan } \\
\text { Signifikan }\end{array}$} \\
\hline & Sikap & $\rightarrow$ & Minat & & & \\
\hline $\mathrm{H} 2$ & \begin{tabular}{|l|} 
Norma \\
Subjektif
\end{tabular} & $\rightarrow$ & Minat & 0.503 & $<0.001$ & Signifikan \\
\hline $\mathrm{H} 3$ & \begin{tabular}{|l|} 
Kontrol \\
Perilaku \\
Persepsian \\
\end{tabular} & $\rightarrow$ & Minat & -0.035 & 0.374 & $\begin{array}{l}\text { Tidak } \\
\text { Signifikan }\end{array}$ \\
\hline $\mathrm{H} 4$ & \begin{tabular}{|l|} 
Kontrol \\
Perilaku \\
Persepsian \\
\end{tabular} & & Perilaku & -0.110 & 0.148 & $\begin{array}{l}\text { Tidak } \\
\text { Signifikan }\end{array}$ \\
\hline $\mathrm{H} 5$ & $\begin{array}{l}\text { Kepercayaan } \\
\text { terhadap } \\
\text { pemerintah }\end{array}$ & $\rightarrow$ & Perilaku & 0.001 & 0.498 & $\begin{array}{l}\text { Tidak } \\
\text { Signifikan }\end{array}$ \\
\hline H6 & Minat & $\rightarrow$ & Perilaku & 0.549 & $<0.001$ & Signifikan \\
\hline
\end{tabular}

Berdasarkan tabel pengujian hipotesis diketahui bahwa :

1. Pengaruh Sikap terhadap Minat Patuh Pajak memiliki koefisien bernilai 0.414 (bertanda positif) dengan nilai $\mathrm{p}<0.001$. Hal ini menunjukkan bahwa terdapat pengaruh yang positif signifikan antara Sikap terhadap Minat Patuh Pajak. Dengan demikian $\mathbf{H 1}$ diterima.

2. Pengaruh Norma Subjektif terhadap Minat Patuh Pajak memiliki koefisien bernilai 0.503 (bertanda positif) dengan nilai $\mathrm{p}<$ 0.001. Hal ini menunjukkan bahwa terdapat pengaruh yang positif signifikan antara Norma Subjektif terhadap Minat Patuh Pajak. Dengan demikian $\mathbf{H 2}$ diterima.

3. Pengaruh Kontrol Perilaku Persepsian terhadap Minat Patuh Pajak memiliki koefisien bernilai -0.035 (bertanda negatif) dengan nilai $\mathrm{p}=0.374$. Hal ini menunjukkan bahwa tidak terdapat pengaruh yang positif signifikan antara Kontrol Perilaku Persepsian terhadap Minat Patuh Pajak. Dengan demikian H3 ditolak.

4. Pengaruh Kontrol Perilaku Persepsian terhadap Perilaku memiliki koefisien bernilai -0.110 (bertanda negatif) dengan nilai $\mathrm{p}=0.148$. Hal ini menunjukkan bahwa tidak terdapat pengaruh yang positif signifikan antara Kontrol Perilaku Persepsian terhadap Perilaku. Dengan demikian $\mathbf{H 4}$ ditolak.

5. Kepercayaan terhadap pemerintah terhadap Perilaku memiliki koefisien bernilai 0.001 (bertanda positif) dengan nilai $\mathrm{p}=0.498$. Hal ini menunjukkan bahwa tidak terdapat pengaruh yang positif signifikan antara kepercayaan terhadap pemerintah terhadap Perilaku. Dengan demikian $\mathbf{H 5}$ ditolak.
6. Pengaruh Minat terhadap Perilaku memiliki koefisien bernilai 0.549 (bertanda positif) dengan nilai $\mathrm{p}<0.001$. Hal ini menunjukkan bahwa terdapat pengaruh yang positif signifikan antara Minat terhadap Perilaku. Dengan demikian H6 diterima.

\section{PEMBAHASAN}

Berdasarkan hasil analisis, sikap dan norma subjektif berpengeruh positif terhadap minat patuh pajak serta minat patuh pajak berpengaruh positif terhadap perilaku patuh pajak. Hasil penelitian ini mendukung penelitian Damayanti et al., (2015). Di sisi lain kontrol perilaku persepsian tidak berpengaruh terhadap minat perilaku serta kontrol perilaku persepsian tidak berpengaruh terhadap perilaku patuh pajak. Hal ini menunjukkan bahwa sebenarnya perilaku patuh bukanlah sekedar kewajiban yang harus dilakukan oleh wajib pajak. Tetapi dalam perilaku patuh pajak sangat berperan faktor kesukarelaan. Theory of Planned Behavior sebenarnya lebih cocok untuk mengetahui perilaku yang bersifat wajib dan bukan sukarela. Selain itu hasil penelitian ini juga menunjukkan bahwa kepercaan pemerintah tidak berpengaruh terhadap perilaku patuh pajak. Hasil ini sesuai dengan penelitian yang dilakukan oleh Purnamasari et al.,(2017). Menurut Purnamasari et al., (2017)hal ini terjadi karena sampai saat ini sebenarnya masyarakat belum percaya terhadap pemerintah. Oleh karena itu sebaiknya aparat pemerintah melakukan perbaikan sikap dengan menegakkan kedisplinan, budaya jujur, dan perbaikan sistem hukum yang ada dengan pemberantasan ketidakadilan sehingga mendorong kepercayaan wajib pajak terhadap pemerintah dan hukum.

\section{E. KESIMPULAN DAN SARAN \\ Kesimpulan}

Penelitian ini menganalisis faktor yang mempengaruhi perilaku patuh pajak melalui Theory of planned Behavior dan kepercayaan terhadap pemerintah. Theory of Planned Behavior adalah salah satu teori keperilakuann yang cocok untuk menganalisis perilaku yang sifatnya wajib. Perilaku patuh pajak adalah salah satu perilaku yang wajib dilakukan oleh wajib pajak orang pribadi apabila telah memenuhi syarat subjektif dan objektif, Dari hasil penelitian ini menunjukkan bahwa sikap 
dan norma subjektif berpengaruh positif terhadap minat patuh pajak dan minat patuh pajak berpengaruh positif terhadap perilaku patuh pajak. Sedangkan kontrol perilaku persepsian tidak berpengaruh positif terhadap minat patuh pajak, kontrol perilaku persepsian dan kepercayaan terhadap pemerintah tidak berpengaruh terhadap perilaku patuh pajak.

\section{Saran}

Saran untuk penelitian kedepannya adalah agar peneliti selanjutnya membuat model penelitian dengan menggunakan theory of reasoned action. Karena berdasarkan penelitian ini terlihat bahwa kontrol perilaku persepsian tidak berpengaruh terhadap minat patuh pajak. Hal ini dapat diartikan bahwa dalam perilaku patuh pajak tidak hanya karena adanya kewajiban, tetapi juka kesukarelan dalam membayar pajak.

\section{DAFTAR PUSTAKA}

.Ajzen, I. dan Fishbein, M. 1975. Belief, Attitude, Intention, and Behavior: An. Introduction to Theory and Research. MA: Addison-Wesley.

Ajzen, Icek, 1988. from intentions to actions: attitudes, personality, \& behavior. Chicago: Dorsey Press

Birskyte, L. (2014). The impact of trust in government on tax paying behavior of nonfarm sole proprietors. Scientific Annals of the "Alexandru Ioan Cuza", University of Iaşi Economic Sciences, $61(1), 1-15$

Chucks, A. D., \& Anthony, O. O. (2013). Tax Morale and Its Effect on Taxpayers' Compliance to Tax Policies of the Nigerian Government. IOSR Journal of Business and Management (IOSR$J B M)$, 12(6), 35-55. Retrieved from http://www.iosrjournals.org/iosr$\mathrm{jbm} /$ papers/Vol12issue6/E01263555.pdf?id=6792.

Damayanti, T. W., dan Supomono. (2012). Apa Kata Mereka? Pengetahuan, Sikap, Niat Patuh Calon Pelaku Pajak. Akuntabilitas Jurnal Ilmiah Akuntansi, 12, 114-123.

Damayanti,Theresia woro; Sutrisno; Subekti, Imam; Baridwan, Zaki. 2015. Trust and Uncertainty Orientation: An Efforts to Create Tax Compliance in
Social Psychology Framework. Social and Behavioral Sciences 211. 938 944

Devos, K. (2015). A Comparative Study of Compliant and Non- Compliant Individual Taxpayers in Australia. Journal of Business and Policy Research. 7(2), 180 - 196.

Gunadi. (2005). Fungsi Pemeriksaan Terhadap Peningkatan Kepatuhan Wajib Pajak (Tax Compliance). Jurnal Perpajakan Indonesia. Vol.4 no.5,p4-9.

Hartono, Jogiyanto (2007). Sistem Informasi Keperilakuan. Edisi Revisi. Yogyakarta: Andi Offset.

Jimenez, Peggy dan Iyer, Govin.S. 2016. Tax Compliance in Social Setting: The influence of social norms, Trust in Government, and perceived fairness on taxpayer compliance. Advances in accounting, incorporating Advances in International Accounting xxx.

Kusuma, H. (2018, Mei 3). Penerimaan Perpajakan 2017 Capai Rp/ 1339 Triliun dari Target. Detik.com. Diakses dari https://finance.detik.com/beritaekonomi-bisnis/d-

3795760/penerimaan-perpajakan2017-capai-rp-1339-triliun-91-daritarget.

Levi, M., dan Stoker, L. (2000). Political Trust and Trustworthiness. Annual Review of Political Science, 3, 475-507.

Miller.A. 1974. Political issues and trust in government. The American Political Science Review,68(3), 951-972

Rahayu, Siti Kurnia. 2013. Perpajakan Indonesia. Yogyakarta: Graha Ilmu

Rosid, Aifin.2017. The impact of perceptions of corruption upon intentional non compliance behavior of personal income taxpayers: anIndonesian Perspective. Disertation. School of taxation and business law UNSW business school.

Saad, Natrah. 2009. Fairness Perceptions and Compliance Behaviour: The Case of Salaried Taxpayers in Malaysia after Implementation of the SelfAssessment System. eJournal of 
Tax Research (2009) vol. 8, no. 1, pp. 32-63

Taylor, Shirley and Todd, Peter A (1995). Understanding Information Technology Usage: A Test of Competing Models. Information system research. Vol 6 No 2.pp 144176

Torgler, B. (2002). Tax Morale and Institutions. CREMA Working Paper Series 2003 09, Center for Research in Economics, Management and the Arts (CREMA).

Purnamasari, Pratiwi, Sukirman. (2017). Pengaruh pemahaman, sanksi perpajakan, tingkat kepercayaan Pada pemerintah dan hukum, serta nasionalisme terhadap Kepatuhan wajib pajak dalam membayar PBB-P2 (Studi Pada Wajib Pajak PBB-P2 di Kota Banjar). Jurnal Akuntansi dan Auditing Volume 14/ No. 1 Tahun 2017: 22-39 